\title{
Impulsivity and novel object recognition test of rat model for vascular cognitive impairment after antipsychotics treatment
}

\author{
Ronny T Wirasto ${ }^{1}$, Irwan Supriyanto ${ }^{1}$, Arif Prassetyo ${ }^{1}$, Nunu N Madjid ${ }^{1}$, Susini R Sari ${ }^{1}$, \\ Baiq R Rhadiana ${ }^{1}$, Heru Yulianto ${ }^{1}$, Nur Arfian ${ }^{2}$, Nyoman Kertia ${ }^{3}$ \\ 1 Department of Psychiatry, Faculty of Medicine, Universitas Gadjah Mada, \\ 2 Department of Anatomy, Faculty of Medicine, Universitas Gadjah Mada, \\ ${ }^{3}$ Rheumatology Division, Department of Internal Medicine, Faculty of Medicine, \\ Universitas Gadjah Mada
}

DOI: http://dx.doi.org/10.19106/JMedSci004803201603

\begin{abstract}
Vascular cognitive impairment ( $\mathrm{VCl})$ is a common condition in which no standard treatment has been approved. $\mathrm{VCl}$ is often accompanied by behavioral problems which require psychiatric interventions. The common therapeutic agent used for the acute management is antipsychotic injections. Current findings showed that atypical antipsychotic possess better safety profile for treating behavioral problems related to $\mathrm{VCl}$ compared to typical antipsychotic. In this study, we induced VCl in Sprague Dawley rats between 6-8 weeks old using bilateral carotid communist artery occlusion technique. The subjects were divided into 4 treatment groups: sham, olanzapine, haloperidol, and risperidone groups. Subjects received intramuscular injections of subsequent drugs for 3 days post $\mathrm{VCl}$ induction. Impulsive behavior and object recognition were examined using cliff jumping test and novel object recognition test. The analyses results showed that impulsive behavior was lower in the olanzapine and haloperidol groups compared to sham group, although it was not statistically significant $(p=0.651)$. The results also showed that there were no significant differences in the time spent exploring old and novel objects in all groups $(p=$ $0.945 ; 0.637$ respectively). In conclusion, antipsychotic injection might not be effective to control impulsive behavior post $\mathrm{VCl}$ induction.
\end{abstract}

\section{ABSTRAK}

Vascular cognitive impairment (VCl) merupakan kondisi patologi dengan prevalensi tinggi namun belum ada terapi standar yang telah disetujui. $\mathrm{VCl}$ sering disertai dengan gangguan perilaku yang membutuhkan penanganan psikiatri. Agen terapi yang digunakan pada penanganan akut adalah injeksi antipsikotik. Saat ini antipsikotik atipikal dikatakan lebih baik untuk digunakan dalam penanganan gangguan perilaku akibat $\mathrm{VCl}$ dibandingkan antipsikotik tipikal. Dalam penelitian ini, kami menginduksi $\mathrm{VCl}$ pada tikus Sprague Dawley berumur 6-8 minggu dengan tehnik bilateral carotid communist artery occlusion. Subyek dibagi menjadi 4 kelompok terapi, yaitu kelompok sham, olanzapine, haloperidol, dan risperidone. Subyek mendapatkan obat bentuk injeksi intramuskular sesuai dengan kelompok selama 3 hari pasca induksi $\mathrm{VCl}$. Perilaku impulsif dan kemampuan mengenali obyek diperiksa dengan cliff jumping test dan novel object recognition test. Analisa cliff jumping test menunjukkan bahwa perilaku impulsif kelompok olanzapine dan haloperidol lebih rendah dibandingkan sham, meskipun tidak bermakna secara statistik. Hasil analisa

Corresponding author: irwan_psi@ugm.ac.id 
statistik menunjukkan tidak ada perbedaan waktu yang dihabiskan untuk mengeksplorasi obyek lama dan obyek baru pada semua kelompok. Kesimpulan, injeksi antipsikotik dapat mengendalikan perilaku impulsif pasca induksi $\mathrm{VCl}$.

Keywords: vascular cognitive impairment - antipsychotics - impulsive behavior-object recognitio

\section{INTRODUCTION}

Vascular disruption might induce cerebral damages, particularly ischemic lesions. The brain will experience a series of alterations including infarct evolvement, cellular proliferation in the penumbra, and behavioral deficits. ${ }^{1}$ The term vascular cognitive impairments (VCI) had been coined to account for behavioral and psychological symptoms that were induced by vascular disruptions. The common components are of behavioral, affective, psychotic, and somatic symptoms. ${ }^{2}$ The most common cause of psychiatric consultation however, was violent impulsive behavior, particularly in early phase of the disorder.

VCI is a common condition for which there are no effective approved pharmacological treatments available. It is recommended that non pharmacological intervention should be tried first in the management of behavioral problems related to VCI. However, if the symptoms are severe and non pharmacological interventions failed to address the problems, short term treatment using antipsychotics are recommended., ${ }^{2,3}$ Antipsychotics exert neuroprotective effects against cell death due to environmental stressors. Olanzapine and risperidone, but not haloperidol, stimulated neurogenesis in rat brain areas (e.g. hippocampus) and preserved cholinergic pathways and cognitive function, possibly by increasing levels of nerve growth factor. ${ }^{4-6}$ The typical antipsychotic, haloperidol, have been widely used partly due to its cheap price and wide distribution. Its efficacy is compromised by its long term side effect on cognitive functions. It is therefore atypical antipsychotics which have better safety profile have gradually been considered as a better option. Atypical antipsychotics have been reported to attenuate both cognitive and non-cognitive behavioral impairments in different animal models of neurotoxicity. Their beneficial behavioral effects are not only related to their dopamine and serotonin receptor blockade effects, but also to their effects on neuroprotection, neurotrophins and neurogenesis. ${ }^{7}$

To assess the efficacy of antipsychotics, animal models have been used. If the animal model is to be used to understand pathogenic mechanisms, the animal model should mimic as closely as possible the symptoms, neuropathology, and mechanisms of the disease. Conversely, if the purpose is to demonstrate the potential efficacy of a drug, the animal model could be less complex. ${ }^{8}$ In this study, we used a global ischemia induction technique to mimic VCI which has been reported elsewhere. ${ }^{9-13}$

Although have been widely used, both typical and atypical antipsychotics use for VCI is mostly based on empirical data and expert opinions. Evidence of their efficacy to control behavioral problems and preserve cognitive function is scarce. In this study, we treated rat models of VCI with injections of short acting typicalantipsychotic(haloperidol), shortacting atypical antipsychotic (olanzapine), long 
acting atypical antipsychotic (risperidone), and injection of aquabidest for the sham group.. We observed impulsive behavior and object recognition after treatments.

\section{METHODS}

This study is a quasi experimental study. All subjects underwent surgery to induce global ischemia, modeling a VCI condition. The subjects were then divided into 4 groups: sham, olanzapine, haloperidol, and risperidone groups. Each group received designated treatment after VCI induction for three days (day 1, 2, and 3 after surgery). At day 4, subjects underwent behavioral examination. The protocol of this study was approved by the Ethical Committee of the Faculty of Medicine Universitas Gadjah Mada, Yogyakarta (ethical approval ref KE/FK/573/EC/2016).

\section{Subjects}

The subjects of this study were male Spague Dawley rats age 6-8 weeks old. The weight was between 200-250 gram. All subjects received the same treatments aside from the drug used.

\section{VCI induction}

VCI was induced using bilateral common carotid artery occlusion (BCCAO) technique. The animals were anesthetized by intramuscular (i.m) injection of ketamin (10 $\mathrm{mg} / \mathrm{kg}$ ) and both common carotid arteries were carefully separated from the cervical sympathetic and vagal nerves through a ventral cervical incision. The bilateral common carotid arteries were exposed, isolated and clamped for 20 min. ${ }^{9,13}$

\section{Drugs administration}

After VCI induction, the subjects were divided into four groups, that is sham, olanzapine, haloperidol, and risperidone groups. The sham group received i.m injection of $1 \mathrm{cc}$ aquabidest. The olanzapine group received i.m injection of Zyprexa (olanzapine, Eli Lilly). The haloperidol group received i.m injection of Lodomer (haloperidol lactate, Mersifarma). The risperidone group received i.m injection of Risperdal Consta (long acting risperidone, Janssen). Subjects received single injection per day for three days.

\section{Behavioral examinations}

There were two behavioral traits measured in this study, impulsivity and object recognition. Within 24 hours after treatment completion, subjects were checked for impulsive behavior using cliff jumping test. Each subject was placed on $10 \times 10 \mathrm{~cm}$ stage placed $30 \mathrm{~cm}$ high for 5 minutes. Since rats are afraid of height, normally they will not jump off the stage. Impulsive behavior was established if subject jump off the stage during the experiments. ${ }^{14}$

Novel object recognition test (NORT) was used to test for short term memory and object recognition. The test was conducted in two phase. In the first phase, subjects were allowed to explore freely in a $40 \times 40 \mathrm{~cm}$ box with an object inside the box (old objects). After 5 minutes, a new different object would be introduced (novel object) in the second phase. Rats are curious animal which will explore objects they are not familiar with hence they will spend more time exploring the new object. The time spent exploring the old and novel objects during the second phase were measured. ${ }^{15}$

\section{Data analysis}

The data was analyzed using SPSS ver. 17. Cochran Q analysis was used compared proportion of impulsive subjects between 
the treatment groups. Mann Whitney test was used to analyze if there were differences in the time spent exploring old and novel objects in each groups. Kruskal Wallis test was used to analyze if there were differences in the time spent exploring old and novel objects between groups. Significant level was defined at $\mathrm{p}<$ 0.05 .

\section{RESULTS}

The cliff jumping test results analysis showed that there was no significant difference in impulsive behaviors across treatment groups. Olanzapine and haloperidol groups showed lower rate of impulsive behavior compared to sham group. On the contrary, risperidone group showed higher rate of impulsive behavior compared to sham group (TABLE 1).

TABLE 1. Impulsive behavior based on cliff jumping test results

\begin{tabular}{lccccccc}
\hline \multirow{2}{*}{ Behavior } & \multicolumn{4}{c}{ Groups } & \multicolumn{3}{c}{ Cochran's $Q$} \\
\cline { 2 - 7 } & Sham & Olanzapine & Haloperidol & Risperidone & $\chi^{2}$ & df & p \\
\hline Non-impulsive & $4(0.44)$ & $4(0.57)$ & $4(0.57)$ & $3(0.38)$ & 1.636 & 3 & 0.651 \\
Impulsive & $5(0.55)$ & $3(0.43)$ & $3(0.43)$ & $5(0.63)$ & & & \\
\hline
\end{tabular}

We analyzed if there were any differences in time spent exploring old and novel objects for each group. The sham groups spent almost equal amount of time exploring old and novel objects. Olanzapine and haloperidol groups spent more time exploring old objects. Subjects in the risperidone groups spent more time exploring novel objects. Nevertheless, these differences were not statistically significant (TABLE 2). Next we analyzed if there were any differences in time spent exploring old and novel objects between groups. There were no significant differences between the groups (TABLE 3).

TABLE 2. Analysis of the time spent exploring old and novel objects in the novel object recognition test for each treatment group using Mann Whitney test

\begin{tabular}{lcccccccc}
\hline \multirow{2}{*}{ Groups } & \multicolumn{4}{c}{ Mean (seconds) } & \multicolumn{3}{c}{ Mann Whitney test } \\
\cline { 2 - 9 } & \multicolumn{3}{c}{ Old } & \multicolumn{3}{c}{ Novel } & Z & $\mathrm{p}$ \\
\hline Sham & 26.24 & \pm & 23.49 & 23.38 & \pm & 25.36 & 0.530 & 0.596 \\
Olanzapine & 37.31 & \pm & 55.52 & 25.4 & \pm & 26.24 & 0.064 & 0.952 \\
Haloperidol & 36.34 & \pm & 59.73 & 13.28 & \pm & 27.74 & 0.721 & 0.472 \\
Risperidone & 51.40 & \pm & 76.40 & 83.61 & \pm & 111.71 & 0.105 & 0.959 \\
\hline
\end{tabular}


TABLE 3. Analysis of the time spent exploring old and novel objects in the novel object recognition test between treatment groups using Kruskal Wallis test

\begin{tabular}{|c|c|c|c|c|c|c|}
\hline \multirow[b]{2}{*}{ Objects } & \multicolumn{3}{|c|}{ Mean (seconds) } & \multicolumn{3}{|c|}{ Kruskall Wallis } \\
\hline & & \multicolumn{2}{|c|}{$\begin{array}{l}X^{2} \\
\text { df }\end{array}$} & $\mathrm{P}$ & & \\
\hline \multicolumn{7}{|l|}{ Old } \\
\hline Sham & 26.24 & \pm & 23.49 & 0.375 & 3 & 0.945 \\
\hline Olanzapine & 37.31 & \pm & 55.52 & & & \\
\hline Haloperidol & 36.34 & \pm & 59.73 & & & \\
\hline Risperidone & 51.40 & \pm & 76.40 & & & \\
\hline \multicolumn{7}{|l|}{ Novel } \\
\hline Sham & 23.38 & \pm & 25.36 & 1.702 & 3 & 0.637 \\
\hline Olanzapine & 25.4 & \pm & 26.24 & & & \\
\hline Haloperidol & 13.28 & \pm & 27.74 & & & \\
\hline Risperidone & 83.61 & \pm & 111.71 & & & \\
\hline
\end{tabular}

\section{DISCUSSION}

In this study, we developed a rat model of VCI using bilateral carotid communist artery ligation. We found that impulsive behavior was lower in the groups treated with olanzapine and haloperidol, although it was not statistically significant. There was also no significant difference in the objects recognition test.

Although antipsychotics are among the most effective drugs used in the maintenance of schizophrenia, mania, and acute psychotic reactions, they are also indicated for several other indications, such as delusional disorders, borderline psychoses, neurological conditions, or behavioral disturbances. But studies in these other indications have been less comprehensive and often limited to particular antipsychotics. The use of typical antipsychotics in the elderly, age group in which VCI most common, is strongly limited by severe and intolerable side effects. ${ }^{16}$ Therefore atypical antipsychotics are considered to be a better option.
Patients with behavioral problems related to VCI usually cannot take medication orally. In this condition, injection of short acting antipsychotics becomes recommended solution. In Indonesia, only two short acting antipsychotic injection available. They are haloperidol and olanzapine injections, both of which have been widely use in VCI. In this study, we also administered long acting risperidone. It has been reported that a small amount of risperidone $( \pm 1 \%)$ is released into bloodstream within 24 hours after injection. ${ }^{17}$

Haloperidol and olanzapine reach peak concentration within 1 hour after injection and provide immediate control of the symptoms. But they require multiple injections, causing inconveniences toward the patients. Unlike haloperidol and olanzapine, the administration of risperidone only requires single injection of the drugs. In this study we showed that both haloperidol and olanzapine have better control over impulsive behavior compared to risperidone. This was because risperidone have not reach peak concentration and exerted its antipsychotic property. 
In this study, the treatments were administrated in the first 3 days after VCI induction. Our aim was to limit the cerebral damage as shown by lower behavioral deficits. It was reported previously that 2 to 4 after ischemia, ${ }^{1}$ emphasizing the importance of proper treatment in this period. The administration of antipsychotics in this period protected the brain from further damages, hence better preserving cognitive functions. ${ }^{4}$ Nevertheless we failed to find any significance difference in the object recognition. The sham group spent equal amount of time exploring old and novel objects, olanzapine and haloperidol groups spent more on old objects, and risperidone group spent more time on novel objects.

Due to cognitive impairment, subjects in the shame group could not discriminate the novel from the old objects and spent equal amount of time exploring both. Spending more time on the old objects could be a sign of both anxiety and cognitive impairment. Due anxiety, subjects in the olanzapine and haloperidol groups spent more time on objects they're most familiar with to feel secure. While subjects in the risperidone group were more explorative, suggesting hyperactivity which is a typical finding in VCI.

\section{CONCLUSION}

We found that antipsychotic injections might not be effective to control impulsive behavior post VCI induction. Nevertheless our findings showed that injections with short acting antipsychotic were better in controlling impulsivity compared to long term antipsychotic. Although in the long run, long term atypical antipsychotic might give better outcome. But this need to be further studied. Atypical antipsychotics are considered to have better safety profile, particularly in elderly, compared to typical. ${ }^{7,16}$ In the case of VCI in which the patients are mostly elderly, every antipsychotic treatment must be prescribed at the lowest effective dosage and for the shortest period possible. ${ }^{16}$

\section{ACKNOWLEDGEMENT}

We thanked Mr. Suparno and Rahma Mara Sabirin from Physiology laboratory. We also thanked Fauziyatul Munawarroh, Binowo Cahyadi and Wawan for their assistance during this study.

\section{REFERENCES}

1. Li H, Zhang N, Lin HY, Yu Y, Cai QY, Ma L, et al. Histological, cellular and behavioral assessments of stroke outcomes after photothrombosis-induced ischemia in adult mice. BMC Neurosci 2014; 15(1):1. http://dx.doi.org/10.1186/1471-2202-15-58

2. Kar N. Behavioral and psychological symptoms of dementia and their management. Indian J Psychiatry 2009; 51(Suppl 1):77-86.

3. Baskys A, Hou AC. Vascular dementia: pharmacological treatment approaches and perspectives. Clin Interv Aging 2007; 2(3):327-35.

4. Bastianetto S, Danik M, Mennicken F, Williams S, Quirion R. Prototypical antipsychotic drugs protect hippocampal neuronal cultures against cell death induced by growth medium deprivation. BMC Neurosci 2006; 7(1):28. http://dx.doi.org/10.1186/1471-2202-7-28

5. Wakade CG, Mahadik SP, Waller JL, Chiu FC. Atypical neuroleptics stimulate neurogenesis in adult rat brain. J Neurosci Res 2002; 69(1):72-9. http://dx.doi.org/10.1002/jnr.10281

6. Parikh V, Terry AV, Khan MM, Mahadik SP. Modulation of nerve growth factor and choline acetyltransferase expression in rat 
hippocampus after chronic exposure to haloperidol, risperidone, and olanzapine. Psychopharmacology (Berl) 2004; 172(4):365-74. http://dx.doi.org/10.1007/ s00213-003-1669-6

7. He J, Kong J, Tan QR, Li XM. Neuroprotective effect of atypical antipsychotics in cognitive and non-cognitive behavioral impairment in animal models. Cell Adh Migr 2009; 3(1):12937. http://dx.doi.org/10.4161/cam.3.1.7401

8. Pepeu G. Mild cognitive impairment: animal models. Dialogues Clin Neurosc 2004; 6(4):369-77.

9. Zheng YQ, Liu JX, Wang JN, Xu L. Effects of crocin on reperfusion-induced oxidative/ nitrative injury to cerebral microvessels after global cerebral ischemia. Brain Res 2007; 1138:86-94. http://dx.doi.org/10.1016/j. brainres.2006.12.064

10. Sharifi ZN, Abolhassani F, Zarrindast MR, Movassaghi S, Rahimian N, Hassanzadeh G. Effects of FK506 on hippocampal CA1 cells following transient global ischemia/ reperfusion in wistar rat. Stroke Res Treat 2012; 809417:1-8. http://dx.doi. org/10.1155/2012/809417

11. Martinez G, Musumeci G, Loreto C, Carnazza ML. Immunohistochemical changes in vulnerable rat brain regions after reversible global brain ischaemia. J Mol Histol 2007; 38(4):295-302. http://dx.doi.org/10.1007/ s10735-007-9102-9

12. Hatakeyama $T$, Matsumoto $M$, Brengman JM, Yanagihara T. Immunohistochemical investigation of ischemic and postischemic damage after bilateral carotid occlusion in gerbils. Stroke 1988; 19(12):1526-34. http:// dx.doi.org/10.1161/01.STR.19.12.1526

13. Zhen G, Doré S. Optimized protocol to reduce variable outcomes for the bilateral common carotid artery occlusion model in mice. J Neurosci Methods 2007; 166(1):73-80. http:// dx.doi.org/10.1016/j.jneumeth.2007.06.029

14. Matsuoka Y, Furuyashiki T, Yamada K, Nagai T, Bito H, Tanaka Y, et al. Prostaglandin E receptor EP1 controls impulsive behavior under stress. Proc Natl Acad Sci USA 2005; 102(44):16066-71. http://dx.doi.org/10.1073/pnas.0504908102

15. Antunes M, Biala G. The novel object recognition memory: neurobiology, test procedure, and its modifications. Cogn Process 2012; 13(2):93-110. http://dx.doi. org/10.1007/s10339-011-0430-z

16. Gareri P, García CS, Manfredi VG, Bruni A, Ciambrone P, Cerminara G, et al. Use of atypical antipsychotics in the elderly: a clinical review. Clin Interv Aging 2014; 9:1363-73. http://dx.doi.org/10.2147/CIA. S63942

17. Ramstack M, Grandolfi GP, Mannaert E, D'Hoore P, Lasser RA. Long-acting risperidone: Prolonged-release injectable delivery of risperidone using medisorb \& ograve; microsphere technology. Schizophr Res 2003; 60(1):314. http://dx.doi.org/10.1016/S 0920 9964(03)80260-8 